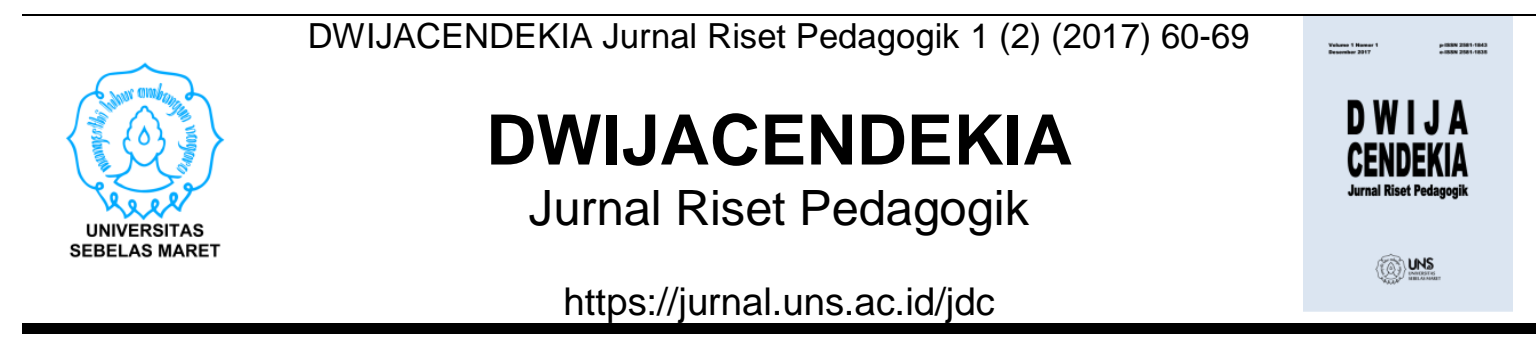

\title{
INOVASI ALAT PERAGA "BELKONSU" DALAM PEMBELAJARAN SUHU DAN PERUBAHANNYA DI SMP NEGERI 2 BLORA
}

\section{Purwanti Indra Tjahyani}

SMPN 2 Blora

\section{Sejarah Artikel}

Diterima 27 Juli 2017

Disetujui 1 November 2017

Diterbitkan 1 Desember 2017

\section{Kata Kunci}

alat peraga, BELKONSU, konversi, suhu

\begin{abstract}
Abstrak
Tujuan penelitian untuk mengetahui bagaimanakah imeplementasi "BELKONSU" dan mengetahui dampaknya terhadap peningkatan hasil belajar peserta didik. "BELKONSU" berupa alat peraga tiga dimensi yang dominan terbuat dari kayu panjang $50 \mathrm{~cm}$, lebar $5 \mathrm{~cm}$ dan tinggi 115 $\mathrm{cm}$, di dalamnya terdapat skala termometer Celsius, Reamur, Fahrenheit dan Kelvin. "BELKONSU" mempunyai karakteristik mudah dibuat, mudah diduplikasi, murah, dan aman. Penelitian ini adalah Penelitian Tindakan Kelas dengan mengimplementasikan "BELKONSU" dalam proses pembelajaran Suhu dan Perubahannya. Teknik pengambilan data menggunakan tes tertulis, unjuk kerja dan observasi penilaian sikap. Hasil penelitian ini menunjukkan bahwa "BELKONSU" mempunyai keunggulan mengatasi miskonsepi materi suhu dan mengkonversi skala suhu dengan cepat, tepat dan akurat sehingga berdampak pada peningkatan hasil belajar aspek pengetahuan, keterampilan dan sikap ilmiah peserta didik dalam pembelajaran Suhu dan Perubahannya Hal ini dikutikan dengan hasil belajar ulangan harian meningkat dari rata-rata 68,8 menjadi 88,45 , unjuk kerja dari $76,8 \%$ menjadi $92,93 \%$, sedangkan penilain sikap dari $70.71 \%$ menjadi $95.96 \%$.
\end{abstract}

\section{Cara Mengutip}

Tjahyani, P.I. (2017). BELKONSU dalam Pembelajaran Suhu dan Perubahannya di SMP Negeri 2 Blora. DWIJACENDEKIA Jurnal Riset Pedagogik, 1(2), 60-69.
Korespondensi Penulis: purwanti_in59_ipapps@yahoo.com
p-ISSN 2581-1843

e-ISSN 2581-1835 


\section{PENDAHULUAN}

Belajar IImu Pengetahuan Alam (IPA) berarti melakukan proses agar peserta didik belajar mempunyai pengetahuan tentang konsep-konsep, prinsipprinsip, hukum dari teori IPA, serta memahami proses keilmuan maupun terampil melakukan percobaan. Wartono, dkk. (2004) menyatakan rinsip pembelajaran IPA berdasarkan pada penciptaan lingkungan yang kondusif sehingga guru dan peserta didik ada secara bersama-sama dalam aktivitas yang saling membelajarkan, yaitu: (1) Prinsip Motivasi : Motivasi ini merupakan dasar dari aktivitas guru dan peserta didik, aktivitas ini perlu ditumbuhkan dan diarahkan ke motivasi intrinsik. (2) Prinsip Latar : guru perlu mengetahui pengetahuan, ketrampilan, dan pengalaman apa yang telah dimiliki peserta didik sehingga kegiatan belajar mengajar tidak berawal dari suatu kekosongan. (3) Prinsip Menemukan: pada dasarnya peserta didik memiliki rasa ingin tahu yang besar sehingga potensi untuk mencari guna menemukan sesuatu discovery terhadap konsep yang akan dipelajari dan sifat konsep tersebut setidaknya mempunyai tantangan. (4) Prinsip Belajar Sambil Melakukan (learning by doing): Pengalaman yang diperoleh melalui bekerja merupakan hasil belajar yang tidak mudah terlupakan. Oleh karena itu, dalam proses belajar mengajar sebaiknya peserta didik diarahkan untuk melakukan kegiatan atau "Learning by Doing". Pembelajaran sambil melakukan menempatkan diri pada dunia peserta didik, dimana peserta didik aktivitas motoriknya masih sangat energik. Metode percobaan dan proyek sangat sesuai untuk mewujudkan prinsip lain.
Alat peraga IPA dalam proses pembelajaran IPA memegang peranan penting yaitu sebagai alat bantu untuk menciptakan proses pembelajaran IPA yang efektif (Nana Sudjana, 2011: 99). Berikutnya menurut R. M. Soelarko (1995), tiaptiap benda yang dapat menjelaskan suatu ide, prinsip, gejala atau hukum alam, dapat disebut alat peraga. Alat peraga merupakan media pengajaran yang mengandung atau membawakan konsep-konsep yang dipelajari. Alat peraga dapat memperjelas bahan pengajaran yang diberikan guru kepada peserta didik sehingga peserta didik lebih mudah memahami materi atau soal yang disajikan guru. Alat peraga juga menarik perhatian peserta didik dan dapat menumbuhkan minat untuk mengikuti pembelajaran IPA.

Alat yang sering digunakan dalam kegiatan pembelajaran Fisika materi Suhu dan Perubahannya adalah termometer namun tidak semua sekolah mempunyai termometer dengan jumlah memadai. Sering karena jumlah yang terbatas dalam pembelajaran termometer dibagikan satu buah tiap kelompok belajar bahkan beberapa guru yang tergabung dalam MGMP Sub Rayon 1 Blora menyatakan jarang menggunakan alat termometer dalam proses pembelajaran materi suhu dan perubahannya karena jumlahnya yang terbatas sehingga materi hanya disampaikan dengan metode ceramah.

Akibatnya peserta didik dapat mengerjakan soal konversi suhu 
karena hafalan rumus yang bersifat matematis bukan karena paham konsep suhu dan perubahannya. Hal ini dibuktikan dengan ulangan harian materi suhu dan perubahannya ratarata 67 ini dicapai peserta didik pada soal konversi suhu dari termometer Celcius ke Reamour dan Celcius ke Kelvin. Soal konversi suhu Celcius, Reamour, ke Fahrenheit atau sebaliknya Fahrenheit konversi ke Celcius, Reamour, peserta didik banyak mengalami kesalahan. Soal semakin banyak yang tak terselesaikan peserta didik pada soal konversi termometer $\mathrm{X}$ misalnya ke termometer yang sudah standar.

Miskonsepsi materi suhu dan perubahannya juga terjadi pada peserta didik yaitu: Peserta didik banyak yang tidak paham konsep suhu dan kalor. Suhu adalah ukuran tingkat atau derajat panas dingnnya suatu benda sedangkan kalor adalah energi panas. Peserta menganggap bahwa keduanya sama. Inilah anggapan peserta didik yang salah. Contoh suhu air panas diember $60^{\circ}$ maka jika dituang dalam 2 (dua) wadah peserta didik akan mengira air mempunyai suhu $30^{\circ}$.

Miskonsepsi suatu benda yang diukur dengan termometer skala Celcius, Reamour dan Fahrenheit ternyata menghasilkan angka yang berbeda, peserta didik menganggap suhu benda itu pasti berbeda (kenyataannya perbedaan itu terjadi karena skala suhunya berbeda) contoh benda mempunyai suhu $100^{\circ} \mathrm{C}, 80^{\circ} \mathrm{R}, 212^{\circ} \mathrm{F}, 373 \mathrm{~K}$ kalau peserta ditanya benda tersebut mempunyai tingkat panas sama atau berbeda? Hampir $90 \%$ peserta didik menjawab berbeda. Untuk meyakinkan bahwa terjadi miskonsepsi pada peserta didik sering penulis lanjutkan dengan pertanyaan benda mana yang paling panas maka peserta didik berturut-turut akan menyebutkan $373 \mathrm{~K}$ yang paling panas kemudian $212^{\circ} \mathrm{F}, 100^{\circ} \mathrm{C}, 80^{\circ} \mathrm{R}$. Dapat dibayangkan apa yang terjadi jika suatu saat disuatu tempat perlu menggunakan thermometer yang tidak biasa digunakan. Di Indonesia menggunakan skala Celcius sedangkan di luar negeri sering menggunakan termometer skala Fahrenheit dan Kelvin.

Sebagai upaya untuk menghilangkan miskonsepsi dan mewujudkan proses pembelajaran Fisika yang menyenangkan penulis dan peserta didik melakukan inovasi alat peraga termometer buatan sendiri dan alat peraga tabel konversi skala suhu "BELKONSU" dalam kegiatan pembelajaran IPA Bab 7 Suhu dan Perubahannya. Tujuan penelitian untuk mengetahui bagaimanakah "BELKONSU" dapat meningkatkan hasil belajar dan mengetahui dampaknya terhadap peningkatan hasil belajar peserta didik.

\section{METODE PENELITIAN}

Penilitian merupakan penelitian tindakan kelas (PTK). Penelitian ini dilaksanakan di SMPN 2 Blora yang berlangsung dari bulan semester 2 tahun ajaran 2016/2017. Subjek 
penelitian ini adalah siswa dan guru kelas VII SMPN 2 Blora.

Data pada penelitian ini ada dua macam, yaitu data mengenai penggunaan BELKONSU dan data mengenai dampak pembelajaran dengan menggunakan BELKONSU terhadap hasil belajar siswa. Adapun teknik pengumpulan data yang digunakan adalah tes tertulis, unjuk kerja dan observasi penilaian sikap.
Teknik uji validitas data pada penelitian ini menggunakan teknik triangulasi, yaitu triangulasi teknik dan sumber. Triangulasi teknik yang digunakan, yaitu, tes, observasi, dan wawancara. Adapun triangulasi sumber yang digunakan, yaitu siswa, guru, dan dokumen. Teknik analisis data yang digunakan dalam penelitian ini yaitu analisis kualitatif deskriptif yang meliputi tiga langkah, yaitu reduksi data, penyajian data, dan penarikan kesimpulan.

\section{PEMBAHASAN}

Alat Peraga BELKONSU

Pada bahasan ini dijelaskan bentuk alat peraga BELKONSU dan cara penggunaannya. Bentuk BELKONSU adalah sebagai berikut.

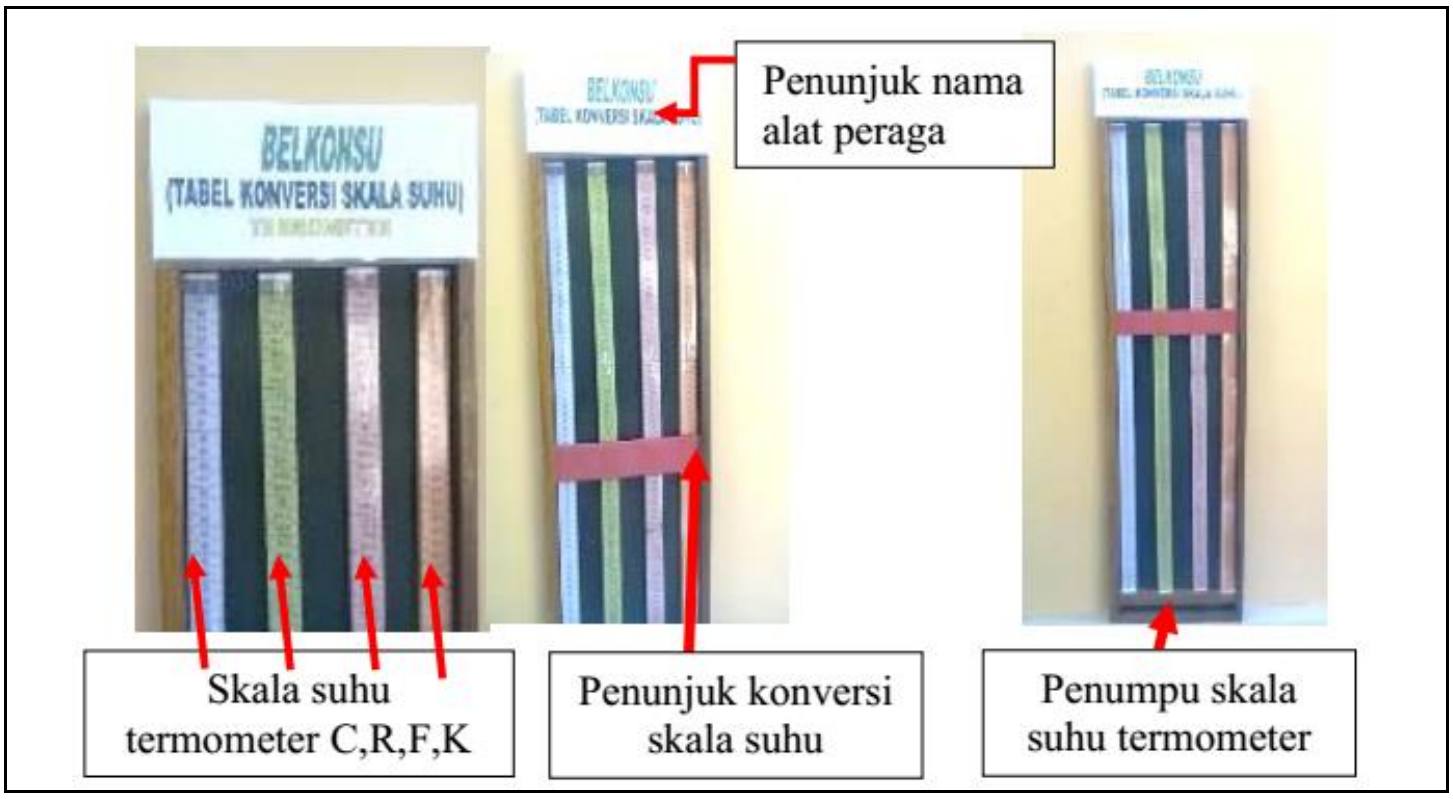

Gambar 1 Alat Pegara BELKONSU

Sedangkan penggunaannya melalui langkah sebagai berikut.

a. Alat peraga "BELKONSU"dapat digunakan sebagai alat ukur suhu harus dilengkapi dengan termometer yangtelah mempunyai nilai. Contoh termometer Celcius. Misal peserta didik mengukur benda sebesar $95^{\circ} \mathrm{C}$ maka penunjuk skala "BELKONSU" digeser ke arah angka 95 sehingga urutan penunjuk skala akan menunjuk angka pada skala lainya Reamur 76, Fahrenheit 203 dan Kelvin 368

b. Jika menggunakan termometer yang belum diketahui angka tetapnya misal termometer buatan 

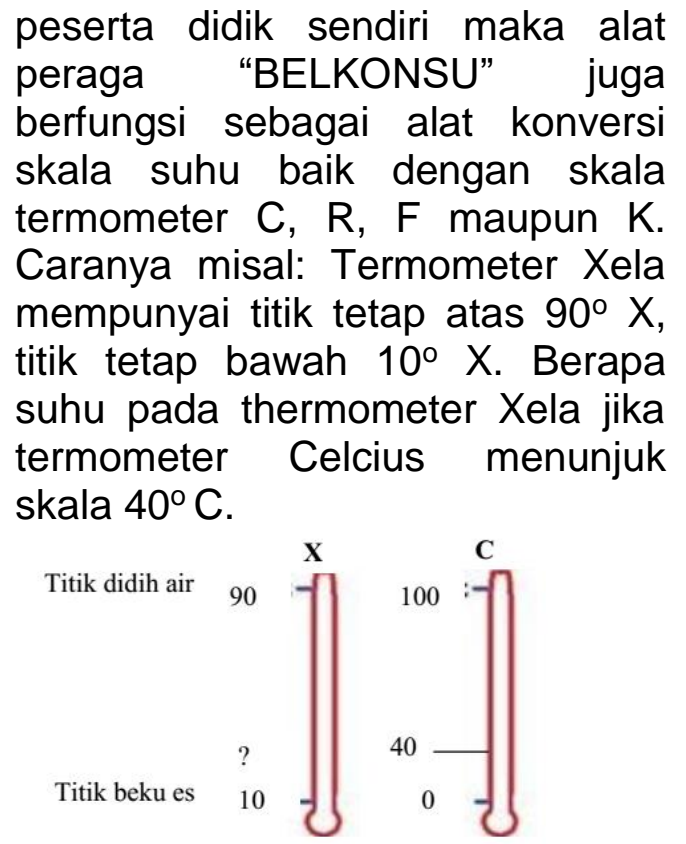

Jawaban :

Maka titik tetap skala X :

$\frac{X-10}{90-10}=\frac{40-0}{100-0}$

$\frac{X-10}{80}=\frac{40-0}{100}$

$$
\begin{gathered}
100(\mathrm{X}-10) \quad=3200 \\
100 \mathrm{X}-1000 \quad=3200 \\
100 \mathrm{X}=3200+1000 \\
\frac{X=4200}{100} \\
X=42
\end{gathered}
$$

Dengan demikian termometer Xela mempunyai skala $42^{\circ}$ jika dikonversi pada skala $\mathrm{C}, \mathrm{R}, \mathrm{F}$, dan $\mathrm{K}$ pada alat peraga "BELKONSU" tertunjuk skala berturut turut adalah $40^{\circ}$ Celcius, $32^{\circ}$ Reamur, $104^{\circ}$ Fahrenheit dan $313^{\circ}$ Kelvin secara cepat, tepat dan akurat.

\section{Implementasi BELKONSU}

Langkah impelementasi BELKONSU

\begin{tabular}{|c|c|c|c|}
\hline Kegiatan & $\begin{array}{l}\text { Langkah- } \\
\text { Langkah } \\
\text { Pembelajaran }\end{array}$ & Deskripsi Kegiatan & $\begin{array}{l}\text { Alokasi } \\
\text { Waktu }\end{array}$ \\
\hline Pendahuluan & $\begin{array}{l}\text { Identifikasi } \\
\text { masalah }\end{array}$ & $\begin{array}{l}\text { Pemusatan perhatian: } \\
\text { Guru menjelaskan termometer berbagai skala, } \\
\text { mengapa diberi nama Celcius, Reamur, } \\
\text { Fahrenheit } \\
\text { Guru memberikesempatan peserta didik untuk } \\
\text { memberikan pendapat. } \\
\text { Guru bertanya tentang tugas membuat } \\
\text { termometr buatan sendiri apakah telah diberi } \\
\text { skala termometer. } \\
\text { Guru menyampaikan tujuan dan manfaat } \\
\text { mempelajari suhu dan pengukurannya. }\end{array}$ & 10 menit \\
\hline Kegiatan Inti & Mengamati & $\begin{array}{l}\text { 1. Peserta didik menunjukkan titip tetap atas } \\
\text { dan titik tetap bawah masing-masing skala } \\
\text { termometer buatannya sendiri }\end{array}$ & \\
\hline
\end{tabular}
dalam pembelajaran mengalami perkembangan tiap siklus. Langkah implementasi pada sikklus III disajikan dalam tabel berikut ini.

Tabel 1 Langkah Pembelajaran Menggunakan BELKONSU 


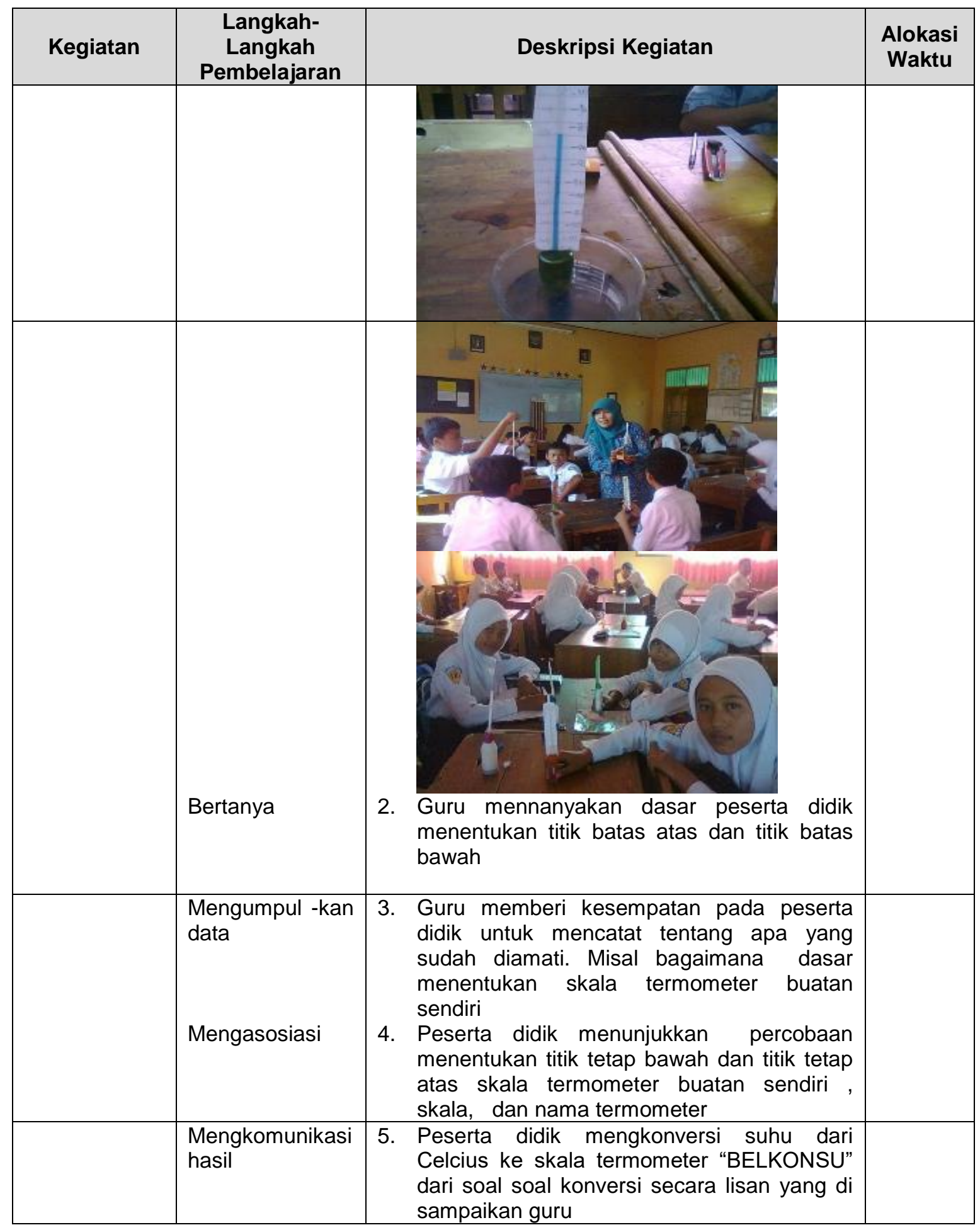




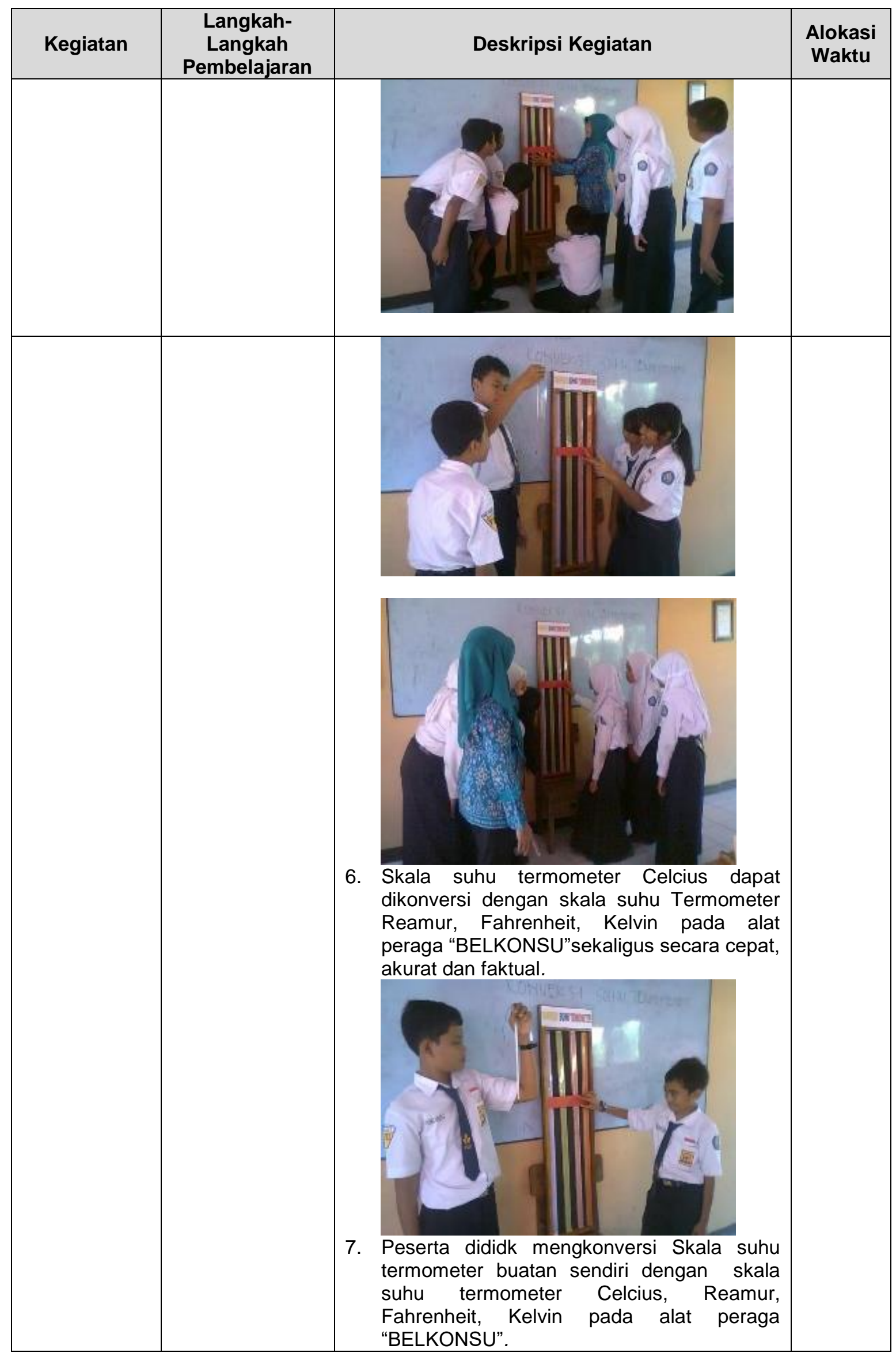




\begin{tabular}{|l|l|l|l|}
\hline Kegiatan & $\begin{array}{c}\text { Langkah- } \\
\text { Langkah } \\
\text { Pembelajaran }\end{array}$ & \multicolumn{1}{|c|}{ Deskripsi Kegiatan } & $\begin{array}{c}\text { Alokasi } \\
\text { Waktu }\end{array}$ \\
\hline & & & \\
\hline Penutup & Termometer \\
buatan sendiri
\end{tabular}

Dampak BELKONSU

\section{a. Data Hasil Belajar Aspek Pengetahuan}

Setelah proses pembelajaran selesai disetiap akhir pembelajaran diadakan tes tertulis. Hal ini untuk mengetahui ketuntasan belajar peserta didik, hasilnya seperti data pada Tabel 2 berikut :

Tabel 2 Data Hasil Ulangan harian Peserta Didik

\begin{tabular}{|c|c|c|c|c|}
\hline Pembelajaran & Rata-rata & $\begin{array}{c}\text { Nilai } \\
\text { Tertinggi }\end{array}$ & $\begin{array}{c}\text { Nilai } \\
\text { Terendah }\end{array}$ & $\begin{array}{c}\text { Ketuntasan } \\
\text { Belajar (\%) }\end{array}$ \\
\hline Pembelajaran 1 & 68,6 & 98,00 & 22,00 & $\mathbf{6 0 , 6}$ \\
\hline Pembelajaran 2 & 79,09 & 100 & 40,00 & $\mathbf{7 8 , 7 8}$ \\
\hline Pembelajaran 3 & 88,45 & 100 & 65,00 & $\mathbf{9 0 , 9 0}$ \\
\hline
\end{tabular}

Berdasarkan Tabel 2. menunjukkan hasil belajar yang cukup baik. Ketuntasan belajar naik secara signifikan. Pada keadaan pembelajaran 1 rata-rata ulangan harian 68,6 dengan ketuntasan belajar $60,6 \%$, pada pembelajaran k-2 mencapai rata-rata 79,09 ketuntasan belajar $78,78 \% \quad$ sedangkan pembelajaran ke 3. Rata-rata 88,45 ketuntasan 90,90\%. Hal ini menunjukkan bahwa penggunaan alat peraga "BELKONSU" pada pembelajaran pertemuan ke 3 berpengaruh positif dan sangat efektif dalam menunjang hasil belajar pengetahuan peserta didik.

b. Data Penilaian Aspek Keterampilan (Unjuk Kerja) Peserta Didik

Data penelitian peserta didik setelah proses pembelajaran selesai pada masing-masing pembelajaran 1, 2, 
dan 3, hasilnya seperti pada Tabel 3 berikut:

Tabel 3 Data Penilaian Keterampilan Peserta Didik

\begin{tabular}{|c|c|c|c|c|c|c|c|}
\hline Pembelajaran & 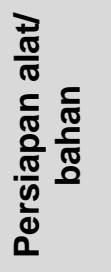 & 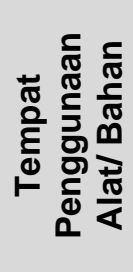 & 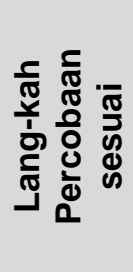 & 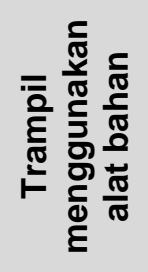 & 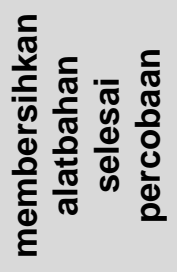 & 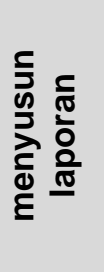 & 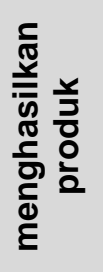 \\
\hline Pembelajaran 1 & 72,73 & 88,8 & 88,89 & 72,73 & 66,67 & 76,77 & 85,86 \\
\hline Pembelajaran 2 & 80,81 & 89,90 & 92,93 & 83,84 & 74,75 & 83,84 & 87,88 \\
\hline Pembelajaran 3 & 90,91 & 94,95 & 95,96 & 3,94 & 89,90 & 92,93 & \\
\hline
\end{tabular}

Berdasarkan Tabel 3 menunjukkan hasil belajar aspek unjuk kerja yang semakin meningkat pada tiap tahap pembelajaran. Aspek yang mempunyai nilai rendah kebersihan setelah melakukan percobaan. Namun pada prinsipnya aspek inipun mengalami peningkatan pada tahap tiap pembelajaran.

\section{c. Data Penilaian Sikap IImiah Peserta Didik}

Proses pembelajaran dengan alat peraga "BELKONSU" sangat bermakna, menarik dan menyenangkan, karena mampu meningkatkan sikap ilmiah peserta didik. Berdasarkan analisis data diperoleh hasil seperti Tabel 3 berikut:

Tabel 4 Analisis Data

\begin{tabular}{|l|c|c|c|c|}
\hline \multirow{2}{*}{$\begin{array}{c}\text { Proses } \\
\text { Pembelajaran }\end{array}$} & \multicolumn{4}{|c|}{ Kategori Sikap IImiah Peserta didik (\%) } \\
\cline { 2 - 5 } & Ingin Tahu & Teliti & Tekun & Komunikasi \\
\hline Pembelajaran 1 & 70,71 & 65,67 & 67,68 & 60,60 \\
\hline Pembelajaran 2 & 86,87 & 81,82 & 82,83 & 79,80 \\
\hline Pembelajaran 3 & 95,96 & 90,91 & 92,93 & 96,97 \\
\hline
\end{tabular}

Berdasarkan Tabel 4. tersebut peningkatan pada setiap tahap menunjukkan sikap ilmiah peserta pembelajaran. Hal ini menunjukkan didik pada masing-masing tahap bahwa pembelajaran menggunakan pembelajaran 1, 2, dan 3 alat peraga "BELKONSU" mampu menunjukkan aspek sikap ilmiah ingin meningkatkan sikap ilmiah peserta tahu, teliti, tekun, dan berkomunikasi didik. peserta didik, cenderung terjadi

\section{SIMPULAN}

Kesimpulan yang dapat diambil dari penelitian ini adalah:

1. Alat peraga Belkonsu mempunyai karakteristik mudah didapat, mudah diduplikasi, murah, dan aman. Dalam proses pembelajaran BELKONSU dapat menghilangkan miskonsepsi tentang suhu dan mengkonversi suhu secara cepat, tepat dan akurat.

2. Alat perga dapat meningkatkan hasil belajar pengetahuan, ketrampilan, dan sikap ilmiah peserta didik kelas 7 pada materi Suhu dan perubahannya 
Berdasarkan kesimpulan diatas, BELKONSU tersebut dapat penulis merekomendasikan diproduksi secara masal melalui diantaranya sebagai berikut:

1. Hasil karya inovasi ini dapat disusun dalam bentuk diktat atau lembar kerja peserta didik (LKS). Dalam diktat tersebut memuat alat bahan yang dibutuhkan, cara membuat alat eksperimen, dan cara penggunaannya.

2. Dengan biaya pembuatan yang relatif murah, alat peraga perusahaan bekerja sama dengan dinas terkait, selanjutnya didistribusikan keberbagai daerah di Indonesia.

3. Alat peraga Belkonsu sebagai alternatif cerdas menggantikan fungsi termometer Reanur, Fahrenheit dan Kelvin sebagai alat pengukur suhu.

\section{DAFTAR PUSTAKA}

Sudjana, Nana. (2011). Dasar - dasar Proses Belajar Mengajar. Bandung:Sinar Baru Algensindo.

Sudjana, Nana. (2011). Penilaian Hasil Proses Belajar Mengajar. Bandung: Remaja Rosdakarya.

Soelarko, R.M. (1995). Media Pendidikan. Jakarta:Raja Grafindo Persada.

Undang -undang No 20 tahun 2003 tentang Sistem Pendidikan Nasional

Wartono, dkk. (2004). Saind. Jakarta: Departemen Pendidikan Nasional. 